\title{
Przegląd polskich nowości wydawniczych
}

\author{
Anna Stanis \\ Biblioteka Uniwersytecka w Warszawie
}

Metody i narzędzia badań piśmiennictwa cyfrowego i jego użytkowników. Pod red. Małgorzaty Góralskiej i Agnieszki Wandel. Wrocław: Wydaw. Uniwersytetu Wrocławskiego, 2016, ss. 220. Seria „Książka-Dokument-Informacja”. Acta Universitatis Wratislaviensis; 3698. ISBN 987-83-229-3514-9

Szybki rozwój zasobów cyfrowych i technologii związanych z ich stosowaniem był inspiracją do dyskusji nad metodologią badań zasobów sieciowych i sposobami ich wykorzystania. Efektem tej dyskusji jest publikacja zawierająca 15 tekstów podzielonych na trzy części tematyczne:

(1) Cyfrowy wymiar bibliologii i informatologii

(2) Zasoby elektroniczne - procesy i perspektywy

(3) Użytkowanie i użytkownicy piśmiennictwa cyfrowego.

W części pierwszej zawarto teksty dotyczące: gatunków tekstu piśmiennictwa cyfrowego, narzędzi analizy zawartości dokumentów cyfrowych, wykorzystania technik komputerowej wizualizacji w badaniach naukometrycznych, badań z zakresu typografii kinetycznej.

W części drugiej znajdują się teksty dotyczące praktycznych aspektów organizowania i wykorzystywania zasobów cyfrowych. Jednym z narzędzi badań bibliotek cyfrowych jest bibliomining czyli „korzystanie z eksploracji danych w badaniach bibliotecznych zasobów danych”. Omówiono model bibliomingu zwracając uwagę na ograniczenia jego wykorzystania przez bariery techniczne, prawne i organizacyjne. Praktyczny aspekt wykorzystania zasobów cyfrowych zawiera również tekst poświecony ocenie działań bibliotek państwowych wyższych szkół zawodowych w zakresie digitalizacji od 1998 do 2014 r. Innym przykładem praktycznego ujęcia tematu jest tekst poświęcony zarządzaniu zbiorami hybrydowymi na przykładzie Biblioteki Głównej Politechniki Warszawskiej. Ciekawym projektem opisanym w tej części publikacji jest utworzenie w 2014 r. na Politechnice Wrocławskiej Centrum Wiedzy i Informacji Naukowo-Technicznej, jednostki ogólnouczelnianej realizującej zadania naukowe, badawcze i usługowe. W strukturze Centrum znajduje się Biblioteka Klasyczna i Biblioteka Elektroniczna stanowiąca podstawę systemu biblioteczno-informacyjnego.

W części trzeciej zawarto badania potrzeb i zachowań użytkowników piśmiennictwa cyfrowego a w szczególności badania wykorzystania e-booków w bibliotekach, badanie czytelnictwa płatnych treści przez wydawców prasowych, wykorzystanie naukowych zasobów cyfrowych przez studentów w kontekście badań zagranicznych. Większość badań nad e-bookami w bibliotekach to badania prowadzone w USA. Kompleksowe badania w tym zakresie realizowane są od 2010 r., osobno dla bibliotek szkolnych, publicznych i akademickich. Temat wykorzystania naukowych zasobów cyfrowych przez studentów podejmowano w wielu krajach ale największe zainteresowanie wzbudził w Indiach (zrealizowano tam połowę wszystkich badań). Stosowaną techniką badawczą najczęściej była ankieta. W tej części pracy znajdują się także tematy dotyczące recepcji polskich czasopism humanistycznych w literaturze światowej oraz badania nad charakterem komunikacji naukowej w sieci (bibliometria, webometria, nowe narzędzia oceny badaczy i ich prac naukowych) na przykładzie komunikacji naukowej pracowników Politechniki Wrocławskiej. 
Fedorowicz-Kruszewska Małgorzata, Cyrklaff Magdalena J.: Media w środowisku osób zagrożonych wykluczeniem społecznym. Toruń, Wyższa Szkoła Bankowa, 2016, ss. 179. ISBN 978-83-943316-1-0

Celem pracy jest opisanie zjawiska wykluczenia społecznego ze szczególnym uwzględnieniem mediów, które dzięki informacji pozyskiwanej za ich pośrednictwem, mogą przyczynić się do zapobiegania zjawisku wykluczenia społecznego. Pojęcie mediów zostało określone „jako nośniki informacji (środki transmisji), do których zalicza się m. in. gazety, książki, filmy, radio, sieci informatyczne”. Autorki osobne rozdziały pracy poświęciły mediom analogowym i cyfrowym. W tej pierwszej grupie znalazły się opisy publikacji brajlowskich, książek dotykowych, tylfografiki („grafiki dla niewidomych i słabo widzących”). W drugiej grupie znajdują się opisy audiobooków, filmów i audycji telewizyjnych dla niesłyszących oraz technologii wspomagających, definiowanych przez autorki za M. Fedorowiczem jako „różnorodne urządzenia elektroniczne, które pozwalają ludziom niepełnosprawnym na samodzielność lub tę samodzielność zwiększają".

Charakterystykę współcześnie funkcjonujących mediów poprzedzają rozdziały poświęcone definicjom pojęcia wykluczenia społecznego (ekskluzji społecznej), przyczynom tego zjawiska, kryteriom kategoryzacji grup zagrożonych wykluczeniem, sposobom zapobiegania wykluczeniu. Omówiono także odzwierciedlenie przeciwdziałania wykluczeniu cyfrowemu w europejskich i polskich dokumentach. Pracę uzupełnia opis organizacji i inicjatyw wspierających rozwój i wykorzystanie mediów, a także obszerna bibliografia, wykaz polecanych zasobów elektronicznych, indeks przedmiotowy.

Włodarczyk Bartłomiej, Woźniak-Kasperek Jadwiga: Język Haset Przedmiotowych Biblioteki Narodowej - od analizy dokumentu do opisu przedmiotowego Warszawa, Wydaw. SBP, 2017, ss. 184. Seria „Nauka, Dydaktyka, Praktyka”; 173. ISBN: 978-83-64203-76-3

W ostatnich latach języki haseł przedmiotowych, w tym język haseł przedmiotowych Biblioteki Narodowej (JHP BN), ulegały licznym przeobrażeniom. Przyczyną tych zmian są m. in. szybko zmieniające się technologie informacyjne, a co za tym idzie - nowe oczekiwania użytkowników bibliotek. JHP BN jest jednym z najbardziej znaczących języków haseł przedmiotowych w Polsce. Tworzony od lat 50. XX w., stosowany był przez wiele lat w bibliografii narodowej, a także do opracowania zbiorów w większości bibliotek publicznych i niektórych bibliotekach naukowych. Prace nad JHP BN w dotychczasowym kształcie zostały zawieszone pod koniec 2015 r. Od stycznia 2016 r. trwają prace nad przekształceniem JHP BN w język deskryptorowy (Deskryptory Biblioteki Narodowej, DBN). W ciągu kilkudziesięciu lat tworzenia JHP BN ukazało się wiele prac o tym języku głównie o charakterze warsztatowym i poradnikowym. Omawiana praca jest - jak piszą we wprowadzeniu autorzy - „dokumentem o charakterze źródłowym, który jest zapisem stanu JHP BN na dzień 30 kwietnia 2014 r." Ten jedyny w swoim rodzaju dokument jest cenną pomocą zarówno dla bibliotekarzy praktyków, którzy opracowują jeszcze dokumenty w JHP BN jak i dla teoretyków JIW oraz studentów kierunków związanych z bibliotekoznawstwem i informacją naukową.

Monografia składa się z trzech części: Część pierwsza w opracowaniu Jadwigi Woźniak-Kasperek omawia niezwykle istotną problematykę analizy dokumentu poprzedzającą powstanie opisu przedmiotowego. Autorka zwraca uwagę na błędy popełniane przy analizowaniu dokumentów, które identyfikowana są z mankamentami JHP. Wyjaśnia często mylone pojęcia katalogowania przedmiotowego i katalogowania rzeczowego, różnice pomiędzy pojęciem treści a pojęciem przedmiotu i omawia podstawowe etapy opracowania przedmiotowego. W tej części znalazły się też podstawowe wiadomości o rodzajach przedmiotu, jego ujęciu i formie.

Część druga w opracowaniu Bartłomieja Włodarczyka poświęcona została charakterystyce JHP $\mathrm{BN}$, również w ujęciu historycznym. Autor tej części omówił szczegółowo różne rodzaje tematów 
w JHP BN, określniki i hasła rozwinięte. Zwrócił uwagę na niejednolitość form jednostek leksykalnych w JHP BN, szczególnie w przypadku tematów ogólnych a także na nie zawsze konsekwentnie ustalane relacje pomiędzy tematami. Wskazując na istotną wartość już istniejących opisów przedmiotowych autor podkreśla, że znajomość zasad tworzenia i stosowania JHP BN jest konieczna zarówno w opracowaniu dokumentów znajdujących się w bibliotekach, jak również w przypadku podejmowania decyzji o jego przekształcaniu.

Praca zawiera także obszerną część trzecią z przykładami dokumentów opracowanych z wykorzystaniem JHP BN. Całość uzupełnia bogata bibliografia załącznikowa i wykaz skrótów.

Nauka o informacji w okresie zmian. Informatologia i humanistyka cyfrowa. Pod red. Barbary Sosińskiej-Kalaty przy udziale Marii Przastek-Samokowej i Zuzanny Wiorogórskiej. Warszawa: Wydaw. SBP, 2016, ss. 276. Miscellanea Informatologica Varsoviensia; vol. 8. Seria „Nauka-Dydaktyka-Praktyka”; 169. ISBN 978-83-64203-67-1

Omawiana pozycja jest pokłosiem trzeciej konferencji z cyklu „Nauka o informacji (informacja naukowa) w okresie zmian", która odbyła się w dniach 11-12 maja 2015 r. ${ }^{1}$, zorganizowanej przez Zakład Systemów Informacyjnych Instytutu Informacji Naukowej i Studiów Bibliologicznych Uniwersytetu Warszawskiego pod patronatem ISKO PL (International Society for Knowledge Organization, The Polish Chapter). Tematem przewodnim konferencji, a zarazem prezentowanej publikacji, było określenie relacji między nauką o informacji (informatologią) a dynamicznie rozwijającą się dziedziną humanistyką cyfrową (e-humanistyką). W książce przedstawiono 17 artykułów powstałych na bazie referatów wygłoszonych na konferencji, pogrupowanych w czterech częściach tematycznych: część I Problematyka, źródła informacji i narzędzia badawcze humanistyki cyfrowej z perspektywy informatologii; część II Badacze nauk humanistycznych w cyfrowym świecie; część III Projekty badawcze, wyniki badań humanistyki cyfrowej oraz dostęp do nich w przestrzeni cyfrowej; część IV Biblioteki akademickie wobec wyzwań humanistyki cyfrowej.

W najobszerniejszej części pierwszej znalazło się osiem artykułów poświęconych: analizie wielkich zasobów danych (big data), z wykorzystaniem zaawansowanych technologii komputerowych (Piotr Gawrysiak), problematyce humanistyki cyfrowej w piśmiennictwie informatologicznym (Barbara Sosińska-Kalata), archiwizacji e-informacji (Małgorzata Góralska), bibliotekom cyfrowym (Widad Mustafa El Hadi), repozytorium danych (Bożena Bednarek-Michalska), prawu autorskiemu (Teresa Święćkowska), społecznościom programistycznym (Sebastian Grabowski) i denatyzacji rzeczywistości (Łukasz Iwasiński).

Część druga zawiera trzy artykuły: Remigiusza Sapy, który omówił zarządzanie indywidualnymi kolekcjami informacji naukowej w humanistyce w świetle piśmiennictwa anglojęzycznego; Marzeny Świgoń na temat technologii w zarządzaniu i dzieleniu się wiedzą i informacją; Małgorzaty Jaskowskiej o wskaźnikach altmetrycznych w systemie wartościowania prac naukowych.

W części trzeciej umieszczono trzy artykuły: dwa pierwsze - Anny Kamińskiej i Darii Rzepieli poświęcono różnym prezentacjom informacji. Trzeci tekst, Marka Nahotki, dotyczy nowych gatunków (cybergatunków) tekstów użytkowych (nieliterackich).

Publikację zamyka część czwarta z trzema artykułami, które poświęcono bibliotekarzom i bibliotekom akademickim, stawianym wobec wyzwań humanistyki cyfrowej (Katarzyna Materska, Lilianna Nalewajska, Anna Myśliwska).

\footnotetext{
${ }^{1}$ Sprawozdanie z tej konferencji ukazało się w Zagadnieniach Informacji Naukowej 2015 nr 1, 145-151.
} 
Nauka o informacji. Pod red. Wiesława Babika. Warszawa, Wydaw. SBP, 2016, ss. 712. Seria „Nauka-Dydaktyka-Praktyka”; 174. ISBN 978-83-64203-82-4

Niezwykle obszerna i szczegółowa monografia obecnego stanu nauki o informacji (informacji naukowej, informatologii), ze szczególnym uwzględnieniem aktualnego rozwoju i przyszłości tej dziedziny nauki. Przeznaczona dla osób zainteresowanych problematyką szeroko rozumianej informacji i działalności informacyjnej. W 24 tekstach, które można uznać za osobne rozdziały, grono pracowników naukowych większości naszych uczelni wyższych, przedstawiło szereg zagadnień z zakresu działalności informacyjnej w Polsce i za granicą. Publikacja jest najobszerniejszym w Polsce kompendium wiedzy o informacji traktowanej z punktu widzenia zarówno teoretycznego, jak i praktycznego. Zminimalizowano kontekst historyczny na rzecz niezbędnych aktualizacji i przedstawienia bieżących problemów informatologii.

W poszczególnych rozdziałach omówiono zagadnienia informacji jako dyscypliny naukowej, jej terminologię, problemy lingwistyczne, obszary badań, metodologię. Zwrócono uwagę na naukę o informacji jako przedmiotu w kontekście kształcenia akademickiego pracowników informacji. Poruszono również zagadnienia organizacji i zarządzania informacją i wiedzą, architektury i prezentacji informacji.

Osobne rozdziały poświęcono środowisku informacyjnemu człowieka, działalności informacyjnej, źródłom informacji, komputerowemu przetwarzaniu informacji, usługom informacyjnym, wyszukiwaniu informacji i zachowaniom informacyjnym. Autorzy mają nadzieję, że przedstawiony w tekstach obraz informacji będzie inspiracją do utworzenia wspólnej badawczej płaszczyzny nad informacją naukową do badań zespołowych o charakterze interdyscyplinarnym.

Monografia pełni również funkcję podręcznika akademickiego informatologii, każdy rozdział uzupełniono bogatą i wyczerpującą bibliografią tematu. Na uwagę zasługuje imponująco rozbudowany aparat pomocniczy składający się z: informacji o autorach; Wykazu ważniejszych skrótów i akronimów; wyboru bibliografii, encyklopedii, informatorów i opracowań; słownika angielsko-polskiego; Indeksu osobowego; Indeksu przedmiotowego.

Morawiec Barbara, Maria: Biblioteki cyfrowe. Tworzenie, zarzadzanie, odbiór. Gliwice: Helion, 2016, ss. 176. ISBN 978-83283-2658-3

W książce przedstawiono wyniki porównania koncepcji architektów bibliotek cyfrowych z potrzebami i oczekiwaniami użytkowników tych bibliotek. Porównanie to poprzedzone zostało omówieniem problemów terminologicznych i wskazaniem celów i funkcji bibliotek cyfrowych. Pracę oparto na przykładach dwóch bibliotek cyfrowych: Małopolskiej Biblioteki Cyfrowej i Jagiellońskiej Biblioteki Cyfrowej, omawiając genezę i rozwój każdej z nich, a także realizację projektów digitalizacyjnych. Obie biblioteki współpracują ze sobą, wykorzystują oprogramowanie dLibra i udostępniają podobne obiekty cyfrowe.

Autorka przedstawiła również ewaluację obu bibliotek, opierając się na analizie zawartości ich stron internetowych w oparciu o kryteria: identyfikacji wizualnej, podstawowych informacji, struktury strony głównej i architektury informacji. Osobny rozdział poświęciła koncepcji architektów bibliotek cyfrowych określając podstawowe funkcje przez nich pełnione w pracy w bibliotece cyfrowej, organizację pracy z uwzględnieniem kontaktu użytkownika biblioteki z architektem.

Ostatni rozdział poświęcono użytkownikom obu bibliotek. W omówionym tu badaniu zastosowano technikę ankiety na podstawie, której scharakteryzowano profile użytkowników i opracowano ich typologię. Wśród oczekiwań użytkowników obu poddanych analizie bibliotek dominują: nieograniczony dostęp do wszystkich publikacji cyfrowych, wiarygodność informacji, możliwość pobierania i kopiowania całości publikacji, sprawne funkcjonowanie i organizacja biblioteki. 
Pracę uzupełnia obszerna bibliografia, indeks osobowy, kwestionariusz przeprowadzonej ankiety, tabele z przedstawieniem dokładnych wyników badań użytkowników obu bibliotek. Publikacja stanowi pracę magisterską autorki powstałą w Instytucie Informacji Naukowej i Bibliotekoznawstwa Uniwersytetu Jagiellońskiego pt. Architekci i użytkownicy bibliotek cyfrowych - konfrontacja koncepcji i oczekiwań.

Nadestano: 17 maja 2017. 